\title{
熏下困難・口腔乾燥に対し補助的漢方治療が 有効であった術後中四頭癌の一例
}

\author{
佐藤 浩子 $\mathrm{a}$ 佐藤 真人 ${ }^{\mathrm{a}}$ 平林 香 $\mathrm{ab}$ \\ 大山 良雄 $\mathrm{ac}$ 紫野 正人 $\mathrm{d}$ 田村 遵一 $\mathrm{a}$ \\ a 群馬大学大学院医学系研究科総合医療学, 群馬, $\overline{\mathbf{T}} 371-8511$ 前橋市昭和町3-39-22 \\ bわたらせリバーサイドクリニック, 群馬, テ376-0011 桐生市相生町1-220-1 \\ c 群馬大学大学院保健学研究科看護学講座, 群馬, $\overline{\mathrm{T}} 371-8514$ 前橋市昭和町3-39-22 \\ d 群馬大学大学院医学系研究科耳鼻咽喉科 - 頭頸部外科学, 群馬, テ371-8511 前橋市昭和町3-39-22
}

\section{A Case of the Oropharyngeal Cancer-Related Dysphagia Effectively Treated by Supportive Kampo Medicine}

\author{
Hiroko SATO ${ }^{\mathrm{a}}$ Mahito SATO $^{\mathrm{a}} \quad$ Kaori HIRABAYASHI $^{\mathrm{ab}}$ \\ Yoshio OHYAMA $^{\text {ac }}$ Masato SHINO $^{\mathrm{d}}$ Jun'ichi TAMURA ${ }^{\mathrm{a}}$
}

a Department of General Medicine, Gunma University Graduate School of Medicine, 3-39-22 Showa-machi, Maebashi, Gunma 371-8511, Japan

b Watarase Riverside Clinic, 220-1 Aioi-cho, Kiryu, Gunma 376-0011, Japan

c Department of Nursing, Gunma University Graduate School of Health Sciences, 3-39-22 Showa-machi, Maebashi, Gunma 371-8514, Japan

d Department of Otolaryngology, Head and Neck Surgery, Gunma University Graduate School of Medicine, 3-39-22 Showamachi, Maebashi, Gunma 371-8511, Japan

\begin{abstract}
An oropharyngeal cancer patient often suffers from dysphagia either due to their disease or as a consequence of their treatment. Here we report a case of a 61-year-old female with the oropharyngeal cancer-related dysphagia, which was effectively treated with Kampo medicine. After four weeks of treatment with hangekobokuto, her swallowing function was improving. Concomitant use of bakumondoto reduced a feeling of xerostomia. She could return to work. The treatment with Kampo medicine might be effective to reduce the cancer-related symptoms and to improve the quality of life of the cancer patients.

Key words : oropharyngeal cancer, dysphagia, xerostomia, palliative medicine

要旨

中咽頭癌術後, 化学放射線療法後の嬩下困難に対し漢方治療が効果的であった症例を経験した。症例は61才女性。 中咽頭癌に対し左扁桃摘出, 両側䅡部郭清術, 続して化学放射線療法を施行された。治療後に自覚した嚥下困難と 口腔乾燥に対し，漢方治療を試みた。半夏厚朴湯エキスを食直前に内服後，嬩下が容易となり摂食時間が短縮した。 麦門冬湯工キスを合方後, 口腔乾燥が軽減した。体重が増加し, 職場復帰の一助となり得た。近年, 癌補助療法や 緩和医療として漢方治療の併用が行われるようになった。中咽頭癌そのものによる, あるいは癌治療に伴う嚥下障 害・口腔乾燥に対し，漢方治療は症状の軽減に役立ち，患者のQuality of Life を向上させる一助になりうると考え られた。

キーワード：中咽頭癌，嚥下困難，口腔乾燥，緩和医療
\end{abstract}

\section{緒言}

中咽頭癌は病態そのもの，また外科手術における 解剖学的損失による四燕下機能低下と, 術後放射線療 法による唾液腺障害などの機能損失などにより患者

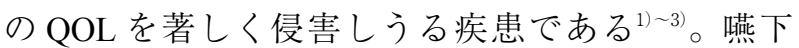

障害に対して術後急性期のリハビリテーション4) 7)， 栄養ケア ${ }^{8)}$ な゙様々な介入がなされているが，患者 の QOL を十分に改善させる治療は報告されていな い。

これまでに星野らは頭頸部癌化学放射線療法後の 
唾液分泌低下に対し, 癌証に対する補剤と併用し麦 門冬湯が有用であるとした9)。山口らは舌癌に対す る放射線療法後に人参養栄湯 10 での漢方治療が有効 であったと報告した。一方，半夏厚朴湯は咽中采戀， あるいは梅核気と言われる咽喉部の違和感に用いら れてきた。近年, 半夏厚朴湯を脳血管障害患者 ${ }^{11}$. パーキンソン病患者 ${ }^{12)}$ に 4 週間投与したところ唾液 中サブスタンス $\mathrm{P}$ が増加し, 燕下反射が有意に改 善したとの報告や，マウスへの半夏厚朴湯の投与に より線条体でドパミンが増加する ${ }^{13)}$ との報告がなさ れ, 半夏厚朴湯は大脳基底核でのドパミン分泌を促 進し，サブスタンス Pの末梢での増加を介して嚥 下反射を改善する機序が示唆された。今回, 中咽頭 癌術後, 化学放射線療法後の嚥下困難と口腔乾燥に 対し半夏厚朴湯と麦門冬湯の兼用が奏効し, 職場復 帰の一助となり得た症例を経験したため, 文献的考 察をふまえながら報告する。

\section{症例}

患 者：61歳女性

主 訴：嚥下困難, 口腔乾燥, 体重減少

現病歴: $X-1$ 年 5 月, 上気道感染症状, 左耳下 腺部の腫脹を自覚, 近医での左扁桃生検で転移性扁 平上皮癌の診断であったため, 同 9 月，精查加療目 的に当院耳鼻咽喉科に紹介された。FDG-PETにて 左扁桃と左澒部リンパ節に FDG の異常集積を認め られ中咽頭側壁癌 Stage IVA(T2N2bMO) と診断され, 当院耳鼻科にて左扁桃摘出, 両側澒部郭清術を施行 された。病理所見は poorly differentiated squamous cell carcinomaであった。術後放射線療法（計60Gy）, 化学療法（シスプラチン $8 \mathrm{mg} \times 20$ 回 + ドセタキセ ル14 mg × 4 回）を施行された。術後, 左軟口蓋挙 上麻瘏の所見あり, また頝部軟部組織の浮腫と, 照 射による唾液分泌障害のため, 燕下困難と口腔乾燥 を強く自覚，食事摂取量が低下し体重も減少した。 耳鼻咽喉科にてピロカルピン $15 \mathrm{mg} /$ 日を処方され たが十分な症状改善が得られなかった。食事時間は 1 回に 1 時間以上を要した。また水等は口に含む量 が多いと嚥下時鼻から吹き出す状態であった。嚥下 や口腔乾燥の改善目的に漢方治療を希望し, $X$ 年 9 月当科に受診した。

現 症：身長 $157 \mathrm{~cm}$, 体重 $41 \mathrm{~kg}$, 血圧 $117 / 92 \mathrm{mmHg}$, 脈拍 $102 \mathrm{bpm}$ ，体温 $36.8^{\circ} \mathrm{C}$ 。頝部に硬性浮腫あり。 嚥下時間の遅延あり。胸部に異常所見なし。腹部䇔
瘦あり，圧痛や肝脾腫はなし。四肢浮腫なし。

漢方医学的所見：自覚症状; 尿の回数が多い, 食 欲がない，食べ物の味がよくわからない，中途覚醒， 寒がり，口腔乾燥，口の中が苦い，のどがつかえる。

他覚的所見：䇔疸著明，脈候：浮沈間，細，弱。 舌候：暗赤色, 厚い湿った黄白色苔。腹候：腹力軟, 腹直筋攣急 $( \pm)$, 胸脇苦満なし, 心下㾂なし, 左 臍傍圧痛 $(+)$, 臍上下悸なし, 心下振水音なし, 小腹不仁なし。

検査所見：当科初診時血液検査所見を表 1 に，ま た手術前，ならびに当科初診時の頚部 CT 並びに FDG-PETの結果を図 1 に示す。初診時, FDG-PET では腫瘍の再発の所見並びに遠隔転移は認められな かった。

経 過: 西洋医学的には, 中咽頭癌術後, 化学放 射線療法後の與下障害, 唾液障害と考えられた。受 診時，放射線療法は終了し，化学療法も副作用のた め継続困難にて経過観察されている状態であった。 漢方医学的には陰証・虚証で気㓌両虚が中心の病態 と考えられ，気血双補剤や，滋陰剤の適応をまず考 慮した。しかし, 嚥下障害のために, 漢方薬の服薬 自体の可否が危惧された。まずは咽中采孌に類似し た病態を考え，先急後緩の法則に従い，半夏厚朴湯 エキスを $7.5 \mathrm{~g} /$ 日で処方し, 食直前に服薬し, 服薬 直後に摂食できるように時間を調整すること，服薬 困難であれば中止することを指導した。 3 週間後の 受診時, 漢方薬を服薬でき, 食事時間が40分に短縮 できたとのこと。一方, 口腔乾燥が気になり飲み込 むのがつらいとの訴えあり，麦門冬湯エキス $6 \mathrm{~g} /$ 日 を合方した。口を湿らす回数が減り, 痰の喀出が可 能となった。さらに食事時間は30分くらいに短縮で きた。2 カ月後，食事時間が短縮したため職場復帰 が可能となった。 5 力月後体重が増加し，唾液分泌 を常時自覚できるようになった。 1 年後, 体重は 4 $\mathrm{kg}$ 増加した。半夏厚朴湯エキス, 麦門冬湯エキス は漸減し，嚥下がつらいと感じたときのみの服薬と した。その後気血両虚を補う目的で十全大補湯エキ ス $2.5 \mathrm{~g} /$ 日に変更したが，その後再び口腔乾燥を訴 えたため, 気陰両虚と考え人参養栄湯エキス $2.5 \mathrm{~g}$ 日に変更し継続した。術後 5 年を経過したが, 体重 は $48.9 \mathrm{~kg}$ と初診時より約 $8 \mathrm{~kg}$ 増加し, 再発・転移 の所見は認められていない。手術時から当科初診後 5 年を経過するまでの経過を図 2 に示す。 
表 1 当科初診時の血液検査所見

\begin{tabular}{|l|r|}
\hline \multicolumn{1}{|c|}{ 検査項目 } & \multicolumn{1}{c|}{ 結果 } \\
\hline ヘモグロビン $(\mathrm{g} / \mathrm{dL})$ & 11.9 \\
\hline 赤血球数 $(/ \mu \mathrm{L})$ & $3.99 \times 10^{6}$ \\
\hline 白血球数 $(/ \mu \mathrm{L})$ & $5.44 \times 10^{3}$ \\
\hline 血小板数 $(/ \mu \mathrm{L})$ & $197 \times 10^{3}$ \\
\hline 総蛋白 $(\mathrm{g} / \mathrm{dL})$ & 6.4 \\
\hline アルブミン $(\mathrm{g} / \mathrm{dL})$ & 4.0 \\
\hline AST $(\mathrm{U} / \mathrm{L})$ & 18 \\
\hline ALT $(\mathrm{U} / \mathrm{L})$ & 10 \\
\hline
\end{tabular}

\begin{tabular}{|l|r|}
\hline \multicolumn{1}{|c|}{ 検査項目 } & \multicolumn{1}{c|}{ 結果 } \\
\hline $\mathrm{LDH}(\mathrm{U} / \mathrm{L})$ & 147 \\
\hline アミラーゼ $(\mathrm{U} / \mathrm{L})$ & 51 \\
\hline 尿素窒素 $(\mathrm{mg} / \mathrm{dL})$ & 18 \\
\hline $\begin{array}{l}\text { クレアチニン } \\
\text { (mg/dL) }\end{array}$ & 143 \\
\hline ナトリウム $(\mathrm{mEq} / \mathrm{L})$ & 4.0 \\
\hline カリウム $(\mathrm{mEq} / \mathrm{L})$ & 108 \\
\hline クロール $(\mathrm{mEq} / \mathrm{L})$ & 80 \\
\hline 血糖 $(\mathrm{mg} / \mathrm{dL})$ & \\
\hline
\end{tabular}

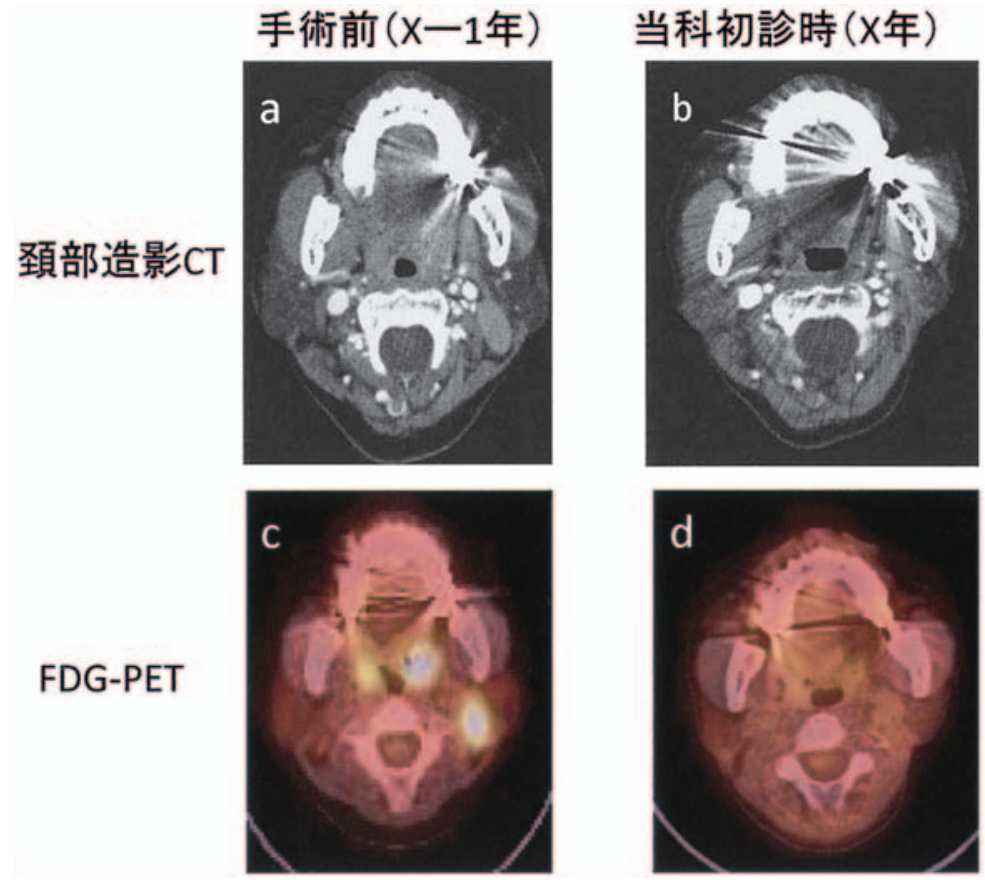

図 1 頝部造影 $\mathrm{CT}$

$\mathrm{a}$ : 手術前 $(X-1$ 年), $\mathrm{b}$ : 当科初診時 ( $X$ 年), 並びに FDG-PET 所見, $\mathrm{c}$ : 手術前 $(X-1$ 年 $), \mathrm{d}$ ：当科初診時 $(X$ 年 $)$

\section{考察}

中咽頭癌患者では, 外科的治療に伴い, 周辺の神 経・筋などの軟部組織や骨への侵襲で形態変化が生 じ，摂食・嚥下関与器官の運動様式が変化する。ま た放射線療法を併用した際には，照射野に唾液腺が 含まれるため，高率に唾液分泌障害による口腔乾燥 を来してくる。また術後瘢痕形成・拘縮や，照射に 伴う被曝組織の線維化により, 可動性が徐々に失わ れ，遅発性に攝食・嚥下動態の異常が生じることも

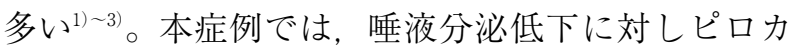

ルピンを内服していたが，唾液分泌は不十分であっ た。さらに，食事摂取は可能ではあったが，嚥下機 能の低下のために摂食に時間が長くかかり，職場復 帰を決断できなかった。半夏厚朴湯エキス内服開始 直後に食事時間が短縮し, 続いて麦門冬湯服薬後に 口内の潤う感じも自覚したため, 漢方治療は症状改 善，QOL 改善に有効であったと考えられた。

半夏厚朴湯は半夏, 获苓, 厚朴, 紫蘇葉, 生姜の 5 味を構成生薬とする薬方である。金匱要略・婦人 雑病篇に「婦人, 咽中采彎在るが如きは半夏厚朴湯 


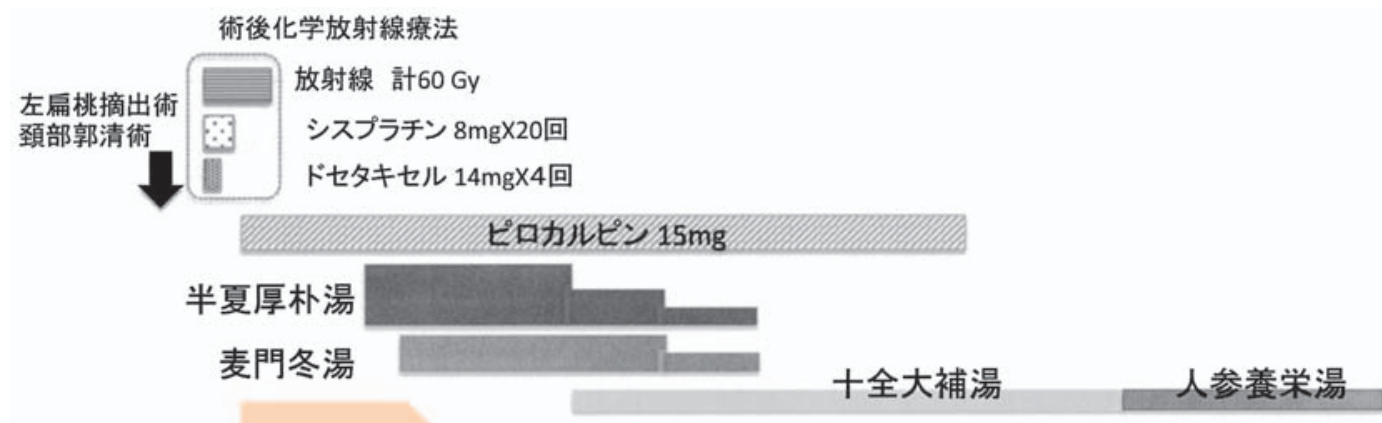

口腔乾燥

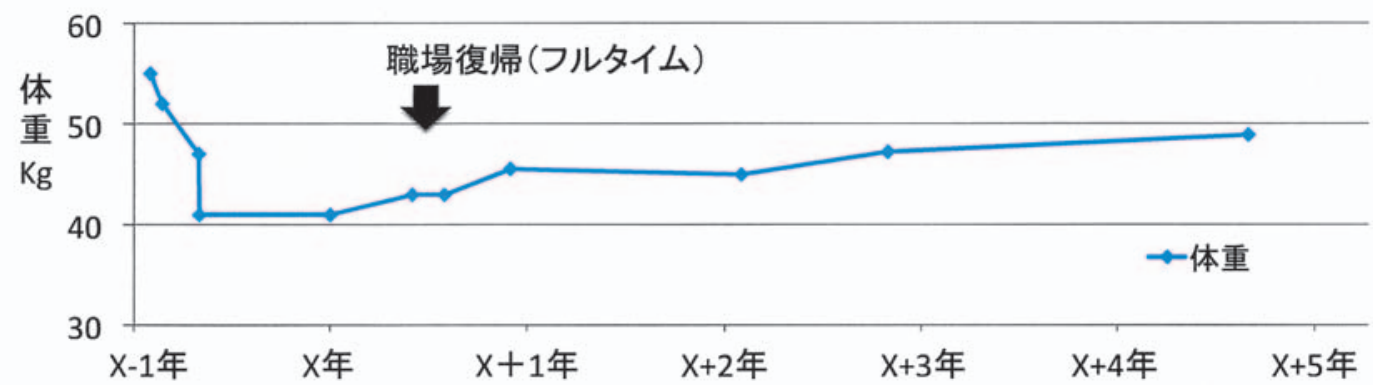

図2 治療経過

之を主る」とあり ${ }^{14)}$, 咽喉頭異常感症に多用される。

『勿誤薬室方函口訣』には，「 $\cdots$ 東郭は水気心胸に 蓄滞して利しがたく, 呉茱莫湯などを用いて倍通利 せざる者, 及び小瘡頭瘡内攻の水腫, 腹脹つよくし て小便甚だ少なき者，この方に犀角を加えて奇効を 取ると云ふ。又浮石を加えて膈䧫の軽症に効あり。 ‥」とあり ${ }^{15)}$, 咽喉頭の異常感症のうち, 浮腫など の水滞をべースとした病態, 気と痰の咽喉部への凝 滞を治すのが半夏厚朴湯の主治とされた。その中で, 「膈嗢の軽症に効あり」は，機能的な病態のみなら ず, 食道狭窄, 癌などの器質的な病態にも用いられ たことを示唆し興味深い。器質的な病態に対する効 果に関してその科学的な機序は明らかではないが, 咽喉頭, 頚部の術後浮腫による嚥下困難を咽中采戀 に近い病態，痰の凝結と考え半夏厚朴湯を処方した ところ, 直ちに食事時間の短縮を自覚することがで きた。

半夏厚朴湯の鑑別処方としては利隔湯が挙げられ る。利隔湯は半夏, 栃子, 附子の 3 味で構成される 方剤である。『勿誤薬室方函口訣』に「七情の気邪 と咽喉の間に相結して，飲食を噎するを噎と曰ふ。 胸膈に結んで，飲食膈下に留つて下らざるを膈と曰 ふ, 膈は猶お治すべし。半夏気を下し，附子邪を散

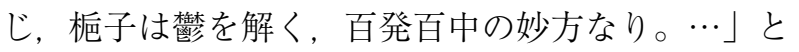

あり ${ }^{16)}$ ，咽頭㾂塞感のうち，特に食道がんによる嚥 下困難，通過障害がある者に対し用いられる。本症 例では咽喉部への痰の凝結の病態と考え鑑別した。

麦門冬湯は麦門冬, 半夏, 粳米, 大雵, 人参, 甘 草の 6 味で構成される。原典は『金厠要略』で,「大 逆上気, 咽喉不利, 逆を止め気を下す者, 麦門冬湯 之を司る」とあり ${ }^{17}$ ，激しい痤攣性の乾性咳嗽によ り咽喉の刺激感を生じる者に用いられる。『勿誤薬 室方函口訣』には「‥咽唾而克渇する者に用いるが 的治なり。」, 「‥老人津液枯稿し, 食物咽につまり， 隔症に似たる者に用ゆ」とあり ${ }^{18)}$, 肺胃の陰虚がベー スの病態に用いられる。本症例に打いても, 麦門冬 湯の服薬により唾液腺障害による口腔乾燥症状が改 善し，麦門冬湯の服薬が乾燥症状改善の一助となっ たと考えられた。本症例では，心下振水音はなかっ たが,「頸部浮腫による嚥下困難」は, 咽喉部付近 の水滞を示す所見と考えられ, 半夏厚朴湯を考慮し た。一方, 坂口は, 重要処方解説として, 半夏厚朴 湯の合方について次のように述べている。「…刺激 性の咳嗽，乾燥して Reizhusten（刺激咳）といわれ ているような状態のときには麦門冬湯合半夏厚朴湯 として用います..${ }^{19)} 」$ 。本症例は咳嗽の症例ではな かったが，半夏厚朴湯に滋陰効果を期待し麦門冬湯 を合方し，効果的であったと考えられた。麦門冬湯 
は前述のように鎮咳目的に使用されることの多い薬 方であるが，その鎮咳作用に関する機序の一つにサ ブスタンス $\mathrm{P}$ などのタキキニン受容体拮抗作用や, タキキニン分解作用などが知られている ${ }^{20)}$ 。サブス タンス Pの動態という点に関しては, 前述の半夏 厚朴湯の燕下反射改善効果 ${ }^{11122}$ と相反する効果と考 えられ，半夏厚朴湯との合方に関しては議論のある ところである。一方で, 麦門冬湯の唾液分泌促進機 序に関しては, 逆に重液中のサブスタンス $\mathrm{P}$, calcitonin-gene-related peptide (CGRP) などの分泌促 進作用 ${ }^{21)}$ な゙が報告されている。本症例において, 唾液分泌の点でピロカルピン単独での効果が十分で なかったことから, このような機序がさらなる乾燥 症状の改善に役立った可能性が示唆される。異なる 作用部位に応じての, 各々の漢方薬の詳細な分子機 序に関して，さらなる科学的検証が待たれる。

口腔乾燥の鑑別処方としては滋陰降火湯, 六味丸, 人参養栄湯などがあげられる。滋陰降火湯は肺結核, 腎孟腎炎などの消耗性高熱時などで津液枯燥・肺熱 を有する例に用いられるが，本症例では熱状は明ら かではなかった。六味丸は腎陰虚の薬方である。本 例でも尿の回数が多いなど六味丸証も併せ持ってい たかもしれない。山口らは, 放射線治療後の口腔が ん患者に対し人参養栄湯にて加療し, 唾液分泌や栄 養状態，貧血などが改善したと報告した ${ }^{10)}$ 。気陰両 虚は気津両傷ともいわれ,「津液が損傷を受けると 津液とともに三焦を巡る気も耗損し，気津が共に衰 えること」と定義され，津液不足と気虚の症候が同 時に見られる病態をいう。治法は益気生津の人参, 五味子, 麦門冬などを配合する ${ }^{22)}$ 。人参養栄湯は人 参, 五味子を含有し, 気陰両虚を改善するため, 頭 頸部癌で化学療法・放射線療法後の症例に適すると 考えられた。本症例では, 嚥下困難, 頸部浮腫の病 態の改善に急を要すると考えられ, 先急後緩の原則 に従い半夏厚朴湯を処方した。嚥下機能の改善後, 気陰両虚を補う人参養栄湯へ変更した。

\section{結語}

嚥下困難，口腔乾燥を訴え受診した中咽頭癌術後 ·化学放射線療法後症例に対し, 漢方治療を行い奏 効した。がん緩和において漢方は, 症状の軽減に役 立ち, 患者の $\mathrm{QOL}$ を向上させる一助となりうると 考えられた。 付記＼cjkstart処方はすべて株式会社ツムラを用いた。本報 告の概要は2014年11月23日2014年度日本東洋医学会群 馬県部会で発表した。

利益相反（COI）に関して開示すべきものなし。

\section{文献}

1) Cousins N, Macaulay F, Lang H, et al. A systematic review of interventions for eating and drinking problems following treatment for head and neck cancer suggests a need to look beyond swallowing and trismus. Oral Oncol $2013 ; 49$ : 387-400.

2 ) Erkal EY, Canoglu-D, Kaya A, et al. Assessment of early and late dysphagia using videofluoroscopy and quality of life questionnaires in patients with head and neck cancer treated with radiation therapy. Radiat Oncol 2014; 9 : 137-147.

3 ）高橋浩二. 頭頸部癌術後摂食・燕下障害への対応. 臨 床栄養 $2007 ; 111 ： 460-470$.

4 ）井上健造. 摂食・嚥下障害のリハビリテーション一口 腔 ·咽頭癌手術後への対応 中咽頭癌手術後の摂食 . 燕下障害. J Clin Rehabil 1998； 7 ：890-895.

5 ) Lazarus CL, Husaini H, Falciglia D, et al. Effects of exercise on swallowing and tongue strength in patients with oral and oropharingeal cancer treated with primary radiotherapy with or without chemotherapy. Int J Oral Maxillofac Surg $2014 ; 43: 523-530$.

6 ) Crary MA, Carnaby GD, LaGorio LA, et al. Functional and physiological outcomes from an exercise-based dysphagia therapy : A pilot intervention of the Mcneill dysphagia therapy program. Arch Phys Rehabil $2012 ; 93: 1173-1178$.

7 ) 溝尻源太郎, 津田豪太. 捸食・噁下障害のリハビリテー ション一口腔 ·咽頭癌手術後への対応 中咽頭癌手術 後のリハビリテーション。 J Clin Rehabil 1998; 7 : 896-901.

8 ）花上伸明, 矢崎涼子, 枝広あや子, 他. 頭頸部癌患者 の栄養ケアの実際。栄養一評価と治療 2009; 26 : 224-228.

9 ）星野惠津夫, 平澤俊明, 春日章良, 他. 緩和医療にお ける漢方の役割。外科治療 $2010 ; 103: 597-607$.

10）山口孝二郎, 向井洋, 浜田倫史, 他. 癌治療後の口腔 内不快症状に人参養栄湯が奏功した 3 症例. 痛みと漢 方 $2012 ; 22: 56-62$.

11) Iwasaki $K$, Wang $Q$, Nakagawa $T$, et al. The traditional chinese medicine banxia houpo tang improves swallowing reflux. Phytomedicine $1999 ; 6: 103-106$.

12) Iwasaki K, Wang Q, Seki H, et al. The effects of the traditional chinese medicine, Banxia Houpo Tang (Hangekoboku-To) on the swallowing reflux in Parkinson's disease. Phytomedicine $2000 ; 7: 259-263$.

13) Kaneko A, Cho S, Hirai K, et al. Hange-Koboku-To, a Kampo medicine, modulates cerebral levels of 5-HT (5-hydroxytryptamine), NA (noradrenaline) and DA (dopamine) 
in mice. Phytother Res $2005 ； 19: 491-495$

14）大塚敬節。金實要略講話. 第一版, 創元社, 大阪 2006. 531-532.

15）長谷川弥人. 勿誤薬室「方函」「口訣」釈義 POD 版. 創元社，大阪 2005.78 .

16）長谷川弥人. 勿誤薬室「方函」「口訣」釈義 POD 版. 創元社，大阪 2005.188 .

17）大塚敬節。金圓要略講話. 第一版, 創元社, 大阪 2006. 179-180.

18）長谷川弥人. 勿誤薬室「方函」「口訣」釈義 POD 版.
創元社，大阪 2005. 71-73.

19）坂口弘. 重要処方講座 (17) 半夏厚朴湯. 漢方医学講座 （日本短波放送放送内容集）1988；43：21-26.

20）宮田健. 漢方鎮咳薬の薬効特性とその発現機序. 医学 のあゆみ 2002；203：209-213.

21) Satoh Y, Itoh H, Takeyama M. Effects of bakumondoto on neuropeptide levels in human saliva and plasma. J Trad Med 2009；26:122-130.

22）神戸中医学研究会. 基礎中医学. 第 9 版, 燎原, 東京 2004. 254. 